\title{
Effect of Standing Litter on Rough Fescue Utilization by Cattle
}

\author{
Darlene M. Moisey, ${ }^{1}$ Walter D. Willms, ${ }^{2}$ and Edward W. Bork ${ }^{3}$ \\ Authors are ${ }^{1}$ Range Management Specialist, Public Lands and Forests Division, Alberta Sustainable Resource Development, Box \\ 471, Provincial Bldg, 5025-49 Ave, St Paul, Alberta, Canada, TOA 3A4; ${ }^{2}$ Range Ecologist, Lethbridge Research Centre, \\ Agriculture and Agri-Food Canada, Box 3000, Lethbridge, Alberta, Canada, T1J 4B1; and ${ }^{3}$ Range Scientist, Dept Agricultural, \\ Food, and Nutritional Science, University of Alberta, 410E, Ag/For Centre, Edmonton, Alberta, Canada, T6G $2 P 5$.
}

\begin{abstract}
Fescue grasslands are well suited to dormant-season grazing, whereas spring defoliation is detrimental to rough fescue (Festuca campestris Rydb.). Dormant-season grazing may also condition fescue plants for subsequent selection in spring by removing standing litter (i.e., senesced biomass). This relationship must be understood in order to manage grazing and conserve rough fescue. This study determined the effects of standing litter on plant selection and utilization by cattle in spring. Forty dormant rough fescue plants were conditioned in fall by removing standing litter in a 4 (treatments) $\times 10$ (blocks) randomized complete block design. This design was repeated with the use of 2 separately grazed paddocks. Treatments were a control (no litter removal) and standing litter removed at 14-, 7-, and 2.5-cm stubble height. Nonparametric plant selection data were analyzed with the use of $\chi^{2}$ methods. Spring biomass utilization was estimated nondestructively through height-weight modeling techniques, and data were analyzed with the use of analysis-of-variance procedures. The stubble height of standing litter affected $(P<0.05)$ plant selection by cattle in the first 2 days of the trial when grazing pressure was light. By the end of the 6-d grazing period $96 \%$ of fescue plants were selected at least once. Additionally, $18 \%$ of plants were regrazed at least once after 3 days, and $48 \%$ after 6 days. Thus, the protective barrier effect of standing litter had limited effect on plant selection by cattle except when grazing pressure was light. However, the degree of spring biomass utilization increased with shorter stubble heights. After 6 days of grazing, the current growth of plants with standing litter removed at $2.5 \mathrm{~cm}$ was utilized at $64 \%$, and control plants were utilized $9 \%$. Therefore, at high grazing pressure the mass of standing litter influenced the degree of utilization, suggesting litter retention is important in limiting grazing impacts on rough fescue.
\end{abstract}

\section{Resumen}

Los pastizales de "Fescue" están bien adaptados al apacentamiento en la época de dormancia, mientras que la defoliación en primavera es perjudicial para el "Rough fescue" (Festuca campestris Rydb.). El apacentamiento en durante la dormancia también puede acondicionar las plantas para la selección subsecuente en primavera al remover el mantillo en pie (i.e., la biomasa senescente); esta relación debe ser entendida para manejar el apacentamiento y conservar el "Rough fescue." Este estudio determinó los efectos del matillo en pie en la selección y utilización de las plantas por el ganado en la primavera. Cuarenta plantas de "Rough fescue" fueron acondicionadas en otoño removiendo el mantillo en pie de ellas y se asignaron a 4 tratamientos en 10 bloques bajo un diseño de bloques completos al azar. Los tratamientos fueron: control (sin remoción del mantillo) y remoción del mantillo en pie a 14,7 y $2.5 \mathrm{~cm}$ de altura del rastrojo remanente, este diseño se repitió usando separadamente dos potreros apacentados. Los datos noparamétricos de la selección de plantas se analizaron con métodos de $\chi^{2}$. La utilización de la biomasa en primavera fue estimada por métodos no destructivos mediante técnicas de modelado de alturapeso y los datos fueron analizados usando procedimientos de análisis de varianza. En los primeros 2 días del ensayo, cuando la presión de apacentamiento fue ligera, la altura del rastrojo del mantillo en pie afectó $(P<0.05)$ la selección de plantas por el ganado. Al final del periodo de apacentamiento de 6 días, $96 \%$ de las plantas de "Rough fescue" fueron seleccionadas al menos una vez. Adicionalmente, $18 \%$ de las plantas fueron re- apacentadas al menos una vez después de 3 días y $48 \%$ después de 6 días. Así, el efecto de barrera protectora del mantillo en pie fue limitado sobre la selección de las plantas por el ganado, excepto cuando la presión de apacentamiento fue ligera. Sin embargo, el grado de utilización de la biomasa en primavera aumentó en las alturas de rastrojo más cortas. Después de 6 días de apacentamiento, el crecimiento de las plantas con remoción de mantillo en pie a $2.5-\mathrm{cm}$ de altura del rastrojo fue utilizado al $64 \%$ mientras que las plantas control se utilizaron $9 \%$. Por lo tanto, con una presión de apacentamiento alta la masa de mantillo en pie influenció el grado de utilización, sugiriendo que la retención de mantillo en pie es importante para limitar los impactos del apacentamiento sobre el "Rough fescue."

Key Words: acid detergent fiber, crude protein, plant selection, Festuca campestris

\section{INTRODUCTION}

Correspondence: Walter D. Willms, Lethbridge Research Centre, Agriculture and AgriFood Canada, Box 3000, Lethbridge, Alberta, Canada, T1J 4B1. Email: willms@agr.gc.ca

Manuscript received 24 February 2005; manuscript accepted 18 December 2005.
Rough fescue (Festuca campestris Rydb.) is the dominant (Strong and Leggat 1992) and most productive forage species in fescue grasslands (Willms et al. 1985) but is also highly sensitive to grazing during the growing season (McLean and 
Wikeem 1985; Willms 1991). The large stature and favorable palatability of fescue when dormant makes these grasslands suitable for fall and winter grazing (Willms and Rode 1998). Dormant-season grazing can reduce the cost of livestock production and may enhance the health of fescue grasslands. However, rough fescue is associated with numerous other forage species that may not be utilized effectively in winter due to their low stature and concealing snow cover (Willms and Rode 1998).

Grazing systems can be devised that strategically utilize grasslands in different seasons throughout the year. Such systems may be necessary for livestock producers who have a limited supply of forage or who wish to encourage more efficient use of all forage. Nevertheless, spring grazing can jeopardize the health of rough fescue.

Forage selection in spring and summer is affected by the presence of litter, which, in turn, has been associated with previous levels of grazing pressure on individual plants (Bakker et al. 1984; Pfeiffer and Hartnett 1995; Laca et al. 2001). Litter, defined as standing or fallen dead herbage from any previous growing season, is avoided by cattle in spring but provides the bulk of forage mass in winter (Willms and Rode 1998). Removing litter from rough fescue during winter grazing may increase the vulnerability of this species to subsequent spring grazing, thereby threatening its viability.

The residual mass and distribution of litter among plants is variable after winter grazing and may be influenced by the presence or absence of snow. In the presence of snow, a small proportion of rough fescue plants were severely grazed but most were lightly grazed or escaped grazing (Willms and Rode 1998). Thus, the vulnerability of plants to grazing may also be highly variable. We conducted a field study to examine the relationship of litter abundance to spring cattle grazing among rough fescue plants in order to predict their vulnerability to grazing disturbance. The hypothesis tested was that standing litter in rough fescue plants is a deterrent to grazing, and would reduce the level of utilization in proportion to its height.

\section{METHODS}

\section{Site Description}

This research was conducted at the Stavely Agriculture and AgriFood Canada research substation in the Porcupine Hills of southwestern Alberta (lat $50^{\circ} 11^{\prime} 30^{\prime \prime} \mathrm{N}$, long $113^{\circ} 53^{\prime} 30^{\prime \prime} \mathrm{W}$; $1366 \mathrm{~m}$ above sea level). The site is within the Foothills Fescue subregion (Strong and Leggat 1992). Moss (1944) and Moss and Campbell (1947) described the vegetation of the Rough Fescue Association at the study site. Parry oat grass (Danthonia parryi Scribn.) is codominant with rough fescue on more xeric sites, whereas bluegrass species (Poa spp L.) are more common on more mesic sites. Smooth aster (Aster laevis L.) and 3-flowered avens (Geum triflorum Pursh.) are common forb species. Although the site had been historically overgrazed (Johnston 1961), it was currently evaluated as having good range condition by the methods described by Wroe et al. (1988).

The study site had a shallow Orthic Black Chernozemic (Udic Haploboral) soil on rolling moraine overlying sandstone (Canada Soil Inventory 1989). The topography of the site was relatively flat with a maximum slope of $5 \%$ and a general southeast exposure. Long-term average annual precipitation was $476 \mathrm{~mm}$ and the average growing season (April to August) precipitation was $300 \mathrm{~mm}$. A nearby weather-monitoring station reported a 30-year average temperature of $5^{\circ} \mathrm{C}$ and an average growing season temperature of $12.9^{\circ} \mathrm{C}$. The suggested stocking rate for the site was 1.61 animal unit months (AUM) $\cdot \mathrm{ha}^{-1}$ (Wroe et al. 1988; Dormaar and Willms 1990).

\section{Experimental Design and Treatments}

Three paddocks, each about 1.3 ha in size, were selected for the study. Two paddocks (A and B) were randomly selected for grazing trials whereas the third $(\mathrm{C})$ was ungrazed and used to determine the plant response to treatment.

Forty rough fescue plants of about equal size (i.e., $20-\mathrm{cm}$ diameter) were selected in November 2000 along a randomly oriented belt transect $(2 \times 50 \mathrm{~m}$, partitioned into $10,2 \times 5 \mathrm{~m}$ blocks) within each of the 3 paddocks and their basal circumferences and average leaf heights were measured. The first 4 sequential plants within a block were randomly assigned to 1 of 4 treatments consisting of a control (no litter removal), litter removed above $14 \mathrm{~cm}$ (i.e., leaving a 14-cm stubble that included current and previously produced biomass on and around the base of the plant); litter removed above $7 \mathrm{~cm}$, and litter removed above $2.5 \mathrm{~cm}$. The latter treatment removed about $95 \%$ of the litter biomass. All plants within a block were no more than $2 \mathrm{~m}$ apart; each plant was mapped to ensure relocation.

Spring-harvested biomass from ungrazed plants in paddock (C) was used to evaluate the subsequent effect of litter-removal treatments on individual plant responses and to provide data for developing predictive models for growth and vertical biomass, crude protein $(\mathrm{CP})$, and acid detergent fiber (ADF) distribution. These models were then applied to the plants exposed to grazing in Paddocks A and B to estimate available and utilized biomass.

Paddocks (A and B) were grazed by 6 cross-bred steers (British breeds; approximate spring weight of $360 \mathrm{~kg}$ ) for 6 days from 30 May to 4 June in spring 2001. The cumulative stocking rate for the period was $1.46 \mathrm{AUM} \cdot \mathrm{ha}^{-1}$. These locally raised cattle were conditioned for about 1 month on a similar plant community before the start of the trial. Water was provided ad libitum. Salt was not provided.

\section{Estimating Available Biomass}

Spring estimates of available current production were derived from estimates of canopy biomass density and adjusted by daily estimates of plant growth over the grazing period. Immediately before grazing, the height of current growth for each plant was recorded and subsequently used to calculate cylindrical canopy volume. Preliminary analysis indicated that plant height of current growth in spring ( 28 May) was affected $(P<0.05)$ by litter-removal treatment (Table 1) and we used plant height growth in the ungrazed paddock $(\mathrm{C})$ as a proxy for growth in the grazed paddocks (A and $\mathrm{B}$ ). Predictive models $(\Delta$ plant height $\cdot \mathrm{d}^{-1}$ ) were developed for each litter-removal treatment by measuring daily plant height during the trial and using regression techniques (not shown). The best growth model based on best fit for each treatment was then applied to the grazed plants, and with the addition of initial height, used to predict their ungrazed height for each day of the grazing trial. 
Plant canopy biomass density $\left(\mathrm{mg} \cdot \mathrm{cm}^{-3}\right)$ was estimated at the end of the grazing trial from estimates of volume and biomass of ungrazed plants in Paddock C. At this time each plant in Paddock $\mathrm{C}$ was harvested at $2.5-\mathrm{cm}$ stubble height and dissected into 5 segments of equal length. Current production was separated from litter and each component was dried $\left(60^{\circ} \mathrm{C}\right)$ to constant weight. The effect of treatment $(\mathrm{df}=3)$ and replicate $(\mathrm{df}=9)$ on canopy biomass density was tested with the use of analysis of variance (ANOVA; SAS 1999) for a randomized complete block against the error term (treatment $\times$ replicate; $d f=27$ ). Because the treatment had no effect $(P=0.78)$ on biomass density, and no relationships $(P>0.10)$ existed between biomass density and initial plant size (including height, basal area, or canopy volume), an unbiased mean canopy biomass density was calculated as $1.99 \mathrm{mg} \cdot \mathrm{cm}^{-3}$. This value was subsequently used as a constant to estimate available biomass of plants within the grazed treatments (Paddocks A and B).

\section{Estimating Selection and Utilization}

The 5 plant-height segments were used to develop models that described the height-biomass and height-nutrient distributions within plants at the end of the grazing trial according to Willms et al. (1980). The utilization of each experimental plant in Paddocks A and B was determined daily by subtracting an estimate of residual biomass from the estimate of ungrazed biomass at the time of sampling. Residual biomass was estimated with the use of the height-biomass distribution model applied to the grazed stubble height and adjusted by the proportion of plant area that was grazed, by the methods reported in Willms et al. (1980). Plant selection was determined by evidence of utilization, and regrazing was judged by observations of one or both evidences that indicate a reduction of grazed stubble height (after adjusting for growth) and an increase of grazed plant area.

\section{Forage Quality Determination}

The vertical distribution of $\mathrm{CP}$ and $\mathrm{ADF}$ within individual rough fescue plants was determined by analyzing the harvested plant segments, which were used to determine height-weight relationships (above). The top 2 segments of current annual growth of each of the 40 fescue plants were combined to obtain sufficient material for testing, which resulted in 4 height samples per plant. Similarly, the top 3 segments of litter (derived only from the 10 undefoliated control plants) were pooled for the same reason (i.e., resulting in 3 height samples per plant). ADF and $\mathrm{CP}$ concentrations were determined with the use of standard analytical methods (973.18 and 976.05, respectively; AOAC 1995).

\section{Data Analysis}

By the time that the grazing trials began in spring, 1 plant from the $2.5-\mathrm{cm}$ stubble height treatment in Paddock A had been destroyed by ground-squirrel activity and was removed from further observations. Therefore, that cell was treated as missing data in subsequent analyses.

Defoliation Effect on Plant Selection by Cattle. Nonparametric accumulative plant selection data from the 2 grazed paddocks ( $\mathrm{A}$ and $\mathrm{B}$ ) were checked for similar trends, and then pooled to facilitate $\chi^{2}$ analysis for goodness of fit. Data from each day of
Table 1. Effect of fall litter removal on the subsequent spring (28 May 2001) height of rough fescue plants in Paddocks $A, B$, and $C(n=10$, except in treatment 2.5 of Paddock $A$, where $n=9 ; P$ [treatment $\times$ paddock effect] $<0.05$ ). Because paddocks influenced the treatment effect on plant height, each paddock was analyzed individually and treatment means were separated with the use of Tukey's multiplecomparison test.

\begin{tabular}{lccc}
\hline & \multicolumn{3}{c}{ Paddock } \\
\cline { 2 - 4 } Treatment $^{1}$ & A (grazed) & B (grazed) & C (ungrazed) \\
\hline \multirow{3}{*}{ Control } & $-0-10 \mathrm{a}^{2}$ & $30 \mathrm{a}$ & $29 \mathrm{a}$ \\
14 & $30 \mathrm{a}$ & $26 \mathrm{ab}$ & $28 \mathrm{a}$ \\
7 & $28 \mathrm{a}$ & $25 \mathrm{~b}$ & $29 \mathrm{a}$ \\
2.5 & $22 \mathrm{~b}$ & $25 \mathrm{~b}$ & $23 \mathrm{~b}$ \\
SEM & 1 & 1.1 & 0.9 \\
$P$ & $<0.05$ & $<0.05$ & $<0.05$ \\
\hline
\end{tabular}

${ }^{1}$ Control indicates no litter removed; 14, litter removed above $14 \mathrm{~cm}$ (leaving $14 \mathrm{~cm}$ of litter on and around the base of the plant); 7 , litter removed above $7 \mathrm{~cm}$; and 2.5 , litter removed above $2.5 \mathrm{~cm}$.

${ }^{2}$ Within a paddock, means followed by different letters differ significantly $(P<0.05)$.

sampling were tested against the hypothesis that plants of all clipping treatments were selected equally $(P>0.05)$. Initial and post hoc tests were analyzed in $4 \times 2$ and $2 \times 2$ contingency tables, respectively. Experiment-wise error was controlled through the Dunn-Sidak procedure (Carr and Lee 2002). Where necessary, significance was determined with the use of Fisher's exact test (Steel et al. 1997). In addition, regrazed plant count data were analyzed with the use of $\chi^{2}$ analysis for goodness of fit in $4 \times 2$ contingency tables, testing the hypothesis that plants of all 4 clipping treatments were equally regrazed (i.e., reselected).

Utilization. Utilization was expressed as a proportion (\%) of total available biomass, after adjusting for plant growth, thus negating the need for covariates related to plant size. Utilization data were tested for homogeneity of variance (Levene's test, SAS 1999) and normality (Shapiro-Wilks tests, SAS 1999) and normalized with the use of a Freeman Tukey arcsin transformation (Zar 1999). The data were then analyzed with ANOVA to test the main effects of paddock, litter-removal treatment, and their interaction, with the use of a mixed linear model (Proc MIXED; SAS 1999). The random factor was blocks nested in paddock, whereas the fixed effects were defoliation treatment and paddock. Initial analysis indicated a significant paddock by treatment interaction $(P<0.01)$. As a result, individual paddocks were tested for the main effect of treatment.

A series of steps were taken to assess the effects of standing litter on grazed plant height for each sampling date. The best polynomial model (based on simplicity and goodness of fit, $R^{2}$ ) that described the relationship of grazed height to the stubble height of standing litter was determined to be a quadratic with the use of regression analyses of pooled data across paddocks. The data were then analyzed to determine the relationships among paddock, stubble height, and its square in an analysis of covariance within the framework of general linear models (Proc GLM; SAS 1999). This analysis did not detect an interaction $(P>0.05)$ of paddock and stubble height, but we detected a paddock effect $(P>0.05)$ at the first 2 sampling dates. 
Table 2. Cumulative number of Festuca campestris plants selected by cattle during spring at increasing cumulative stocking rates from 30 May to 4 June in relation to litter-removal treatments (pooled for Paddocks $A$ and $\left.B^{1}\right)$.

\begin{tabular}{|c|c|c|c|c|c|}
\hline Stocking rate $\left(\mathrm{AUM} \cdot \mathrm{ha}^{-1}\right)$ : & & 0.48 & 0.73 & 1.22 & 1.46 \\
\hline Treatment $^{2}$ & $\mathrm{n}$ & (31 May) & (1 June) & (3 June) & (4 June) \\
\hline Control & 20 & $10 a^{3}$ & $15 a$ & $17 \mathrm{a}$ & $17 \mathrm{a}$ \\
\hline 14 & 20 & $19 b$ & $20 \mathrm{~b}$ & $20 \mathrm{a}$ & $20 \mathrm{a}$ \\
\hline 7 & 20 & $20 \mathrm{~b}$ & $20 \mathrm{~b}$ & $20 \mathrm{a}$ & $20 \mathrm{a}$ \\
\hline 2.5 & 19 & $17 \mathrm{~b}$ & $18 a b$ & $19 \mathrm{a}$ & $19 \mathrm{a}$ \\
\hline
\end{tabular}

${ }^{1}$ The number of plants selected at each sampling time was similar $(P>0.05)$ between paddocks.

${ }^{2}$ Control indicates no litter removed; 14 , litter removed above $14 \mathrm{~cm}$ (i.e., leaving a $14-\mathrm{cm}$ stubble that included current and previously produced biomass on and around the base of the plant); 7 , litter removed above $7 \mathrm{~cm}$; and 2.5, litter removed above $2.5 \mathrm{~cm}$.

${ }^{3}$ Within a column, means followed by different letters differ significantly $(P<0.05)$.

Therefore, a third analysis was conducted to determine the solution for the covariates (Proc GLM; SAS 1999) in a simplified model with stubble height and its square as covariates, and paddock as the main effect for only the first 2 sampling dates. The best model was chosen based on simplicity and goodness of fit $\left(R^{2}\right)$. Separate models were developed for 3 sampling times during the grazing period, which represented different stocking rates. Cumulative stocking rates for these times were determined from the number of animals, paddock size, and duration of grazing, and were $0.48,0.73$, and $1.46 \mathrm{AUM} \cdot \mathrm{ha}^{-1}$, respectively.

Forage Quality. The concentration of $\mathrm{CP}$ and ADF were analyzed with ANOVA for repeated measures (Proc Mixed; SAS 1999), which accounts for autocorrelation among seg- ments of the same plant, to test for the effect of clipping treatment, plant height, and their interaction. Significant $(P<0.05)$ interactions resulted in testing the effect of plant height within a litter-removal treatment to identify trends. Nutrient data from the litter component were analyzed only for the effect of height with the use of ANOVA for repeated measures (SAS 1999). Where the $F$ ratio was significant $(P<0.05)$, least-square means were separated with the use of Tukey's multiple-comparison test.

\section{RESULTS}

\section{Plant Selection}

Litter removal affected $(P<0.05)$ plant selection by cattle, but only within the first 2 days of the trial (cumulative stocking rate $=0.48 \mathrm{AUM} \cdot \mathrm{ha}^{-1}$; Table 2 ). Of the fescue plants sampled, $18 \%$ were regrazed at least once after 3 days, and $48 \%$ after 6 days (cumulative stocking rates $=0.73$ and 1.46 AUM $\cdot$ ha $^{-1}$, respectively). Furthermore, $96 \%$ of plants were selected at least once by the end of the grazing trial (cumulative stocking rate $=1.46 \mathrm{AUM} \cdot \mathrm{ha}^{-1}$ ).

Modeled biomass utilization of rough fescue plants in spring was affected $(P<0.05)$ by the degree of litter removal and paddock (Table 3). Grazing pressure, as determined by cumulative stocking rate, appeared to be an important factor in Paddock A but not Paddock B, where average utilization increased only about $4 \%$ from 31 May to 4 June (cumulative stocking rates $=0.48$ and $1.46 \mathrm{AUM} \cdot \mathrm{ha}^{-1}$, respectively; Table 3). Nevertheless, biomass utilization of each treatment was similar between paddocks at the end of the grazing trial.

Table 3. Arithmetic least-square means of Festuca campestris biomass utilization (percent plant removed as predicted from available biomass and utilization models) by cattle in spring at increasing cumulative stocking rates from 30 May to 4 June in relation to litter-removal treatments. Results from the paddocks are reported separately because of a paddock $\times$ treatment interaction $(P<0.05)$.

\begin{tabular}{|c|c|c|c|c|c|c|}
\hline Stocking rate $\left(\mathrm{AUM} \cdot \mathrm{ha}^{-1}\right)$ : & & & 0.48 & 0.73 & 1.22 & 1.46 \\
\hline \multirow[t]{2}{*}{ Paddock } & Treatment $^{1}$ & $n$ & (31 May) & (1 June) & (3 June) & (4 June) \\
\hline & & & --------- & --------Ut & ) ----------- & ------ \\
\hline \multirow[t]{6}{*}{$A$} & Control & 10 & $5 a^{2}$ & $7 \mathrm{a}$ & $9 \mathrm{a}$ & $8 \mathrm{a}$ \\
\hline & 14 & 10 & $14 a b$ & $19 a b$ & $22 \mathrm{~b}$ & $22 \mathrm{~b}$ \\
\hline & 7 & 10 & $30 \mathrm{~b}$ & $33 \mathrm{~b}$ & $40 \mathrm{c}$ & $40 \mathrm{c}$ \\
\hline & 2.5 & 9 & $36 \mathrm{bA}^{3}$ & $43 \mathrm{bA}$ & $59 d$ & $60 d$ \\
\hline & SEM & $n=100$ & 5.4 & 5.3 & 3.7 & 3.5 \\
\hline & & $n=9$ & 5.8 & 5.7 & 4.0 & 3.7 \\
\hline \multirow[t]{5}{*}{ B } & Control & 10 & $6 a$ & $7 \mathrm{a}$ & $9 a$ & $10 \mathrm{a}$ \\
\hline & 14 & 10 & $20 \mathrm{~b}$ & $22 \mathrm{~b}$ & $21 \mathrm{~b}$ & $20 \mathrm{~b}$ \\
\hline & 7 & 10 & $42 \mathrm{c}$ & $43 \mathrm{c}$ & $44 \mathrm{c}$ & $43 c$ \\
\hline & 2.5 & 10 & $68 \mathrm{~dB}$ & $68 \mathrm{~dB}$ & $69 \mathrm{~d}$ & $68 d$ \\
\hline & SEM & $n=10$ & 2.4 & 2.1 & 1.8 & 2 \\
\hline \multicolumn{3}{|l|}{ Source of variation } & ------------ & ----------- ( & ------------ & ---------- \\
\hline \multicolumn{3}{|l|}{ Treatment $(\mathrm{T})$} & $<0.01$ & $<0.01$ & $<0.01$ & $<0.01$ \\
\hline \multicolumn{3}{|l|}{ Paddock (P) } & $<0.01$ & 0.02 & 0.31 & 0.32 \\
\hline \multicolumn{3}{|l|}{$\mathrm{T} \times \mathrm{P}$} & 0.01 & 0.03 & 0.3 & 0.36 \\
\hline
\end{tabular}

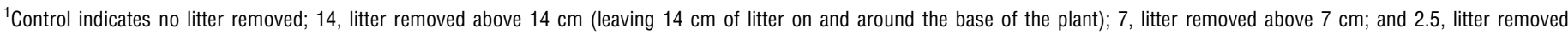
above $2.5 \mathrm{~cm}$.

${ }^{2}$ Tests derived from arcsin-transformed values. Within a paddock and column, means followed by different lower-case letters are significantly different $(P<0.05)$.

${ }^{3}$ Within a column, paired means of the same treatment with a different upper-case letter are significantly different $(P<0.05)$. 
Rough fescue biomass was generally utilized above the height of litter $(2.5-14 \mathrm{~cm})$ throughout the trials, and only the litter of untreated plants became less effective as a protective barrier as cumulative stocking rate increased (Fig. 1). This is illustrated by a quadratic relationship of grazed height with increasing stubble height of standing litter $(P<0.001)$, which resulted in a greater deflection of the regression line as cumulative stocking rates increased (Fig. 1).

\section{Forage Quality and Nutrient Distribution}

Both ADF and CP concentrations (\%) in litter were not affected $(P>0.05)$ by the vertical distribution of plant segments within the plant (Table 4). The extent of litter removal had no effect $(P=0.41)$ on ADF concentration within current years' growth, but ADF concentration was reduced $(P=0.03)$ across segments as defined by their vertical distribution within the plant (Table 4). The top segment had an average of $4 \%$ less ADF than the lowest segment.

Similarly, the CP concentration (\%) of current growth increased $(P<0.05)$ with each vertical segment from the bottom of the plant to the top (Table 4). The upper 2 segments had an average of $5.6 \%$ more $\mathrm{CP}$ than the bottom segment.

\section{DISCUSSION}

\section{Plant Selection}

The protective effect of litter had limited impact in determining whether rough fescue plants were selected by cattle, except when grazing pressure was light (Table 2). This is in contrast to O'Reagain and Grau (1995) who determined that animals grazed $80 \%-100 \%$ of tillers on preferred species before selecting plant species that were typically avoided. However, within a species, plant selection has been shown to decline with more standing litter (Pfeiffer and Hartnett 1995), reproductive stems (Ganskopp et al. 1992; Flores et al. 1993), or high levels of litter accumulation (Willms and Rode 1998).

\section{Utilization}

Cattle readily identified and utilized biomass of plants where litter had been removed (Table 3) and thus showed a strong aversion to grazing litter. Ganskopp et al. (1993) reported that cattle were aware of even a single cured stem in crested wheatgrass [Agropyron cristatum (L.) Gaertn.] tussocks, which affected their utilization of those plants. In our study, control plants were grazed lightly, suggesting some protection from grazing due to tall standing litter (Fig. 1). Rough fescue typically produces very few reproductive tillers and consists primarily of long, pliant basal leaves that create an open canopy. This results in low litter density at the top of a tuft, which allows the more erect new leaves to emerge. The stubble of litter in treated plants likely provided a much greater deterrent to grazing below its height than the leaf blades in the upper canopy. As a result, most utilized biomass occurred above the stubble height of litter (Fig. 1). Therefore, the steers utilized the new fescue growth in inverse proportion to the stubble height of standing litter (Table 3).

Contrary to the steers in Paddock A, the steers in Paddock B utilized the total biomass consumed over the trial period in the first day (Fig. 1), which indicated rapid recognition of preferred
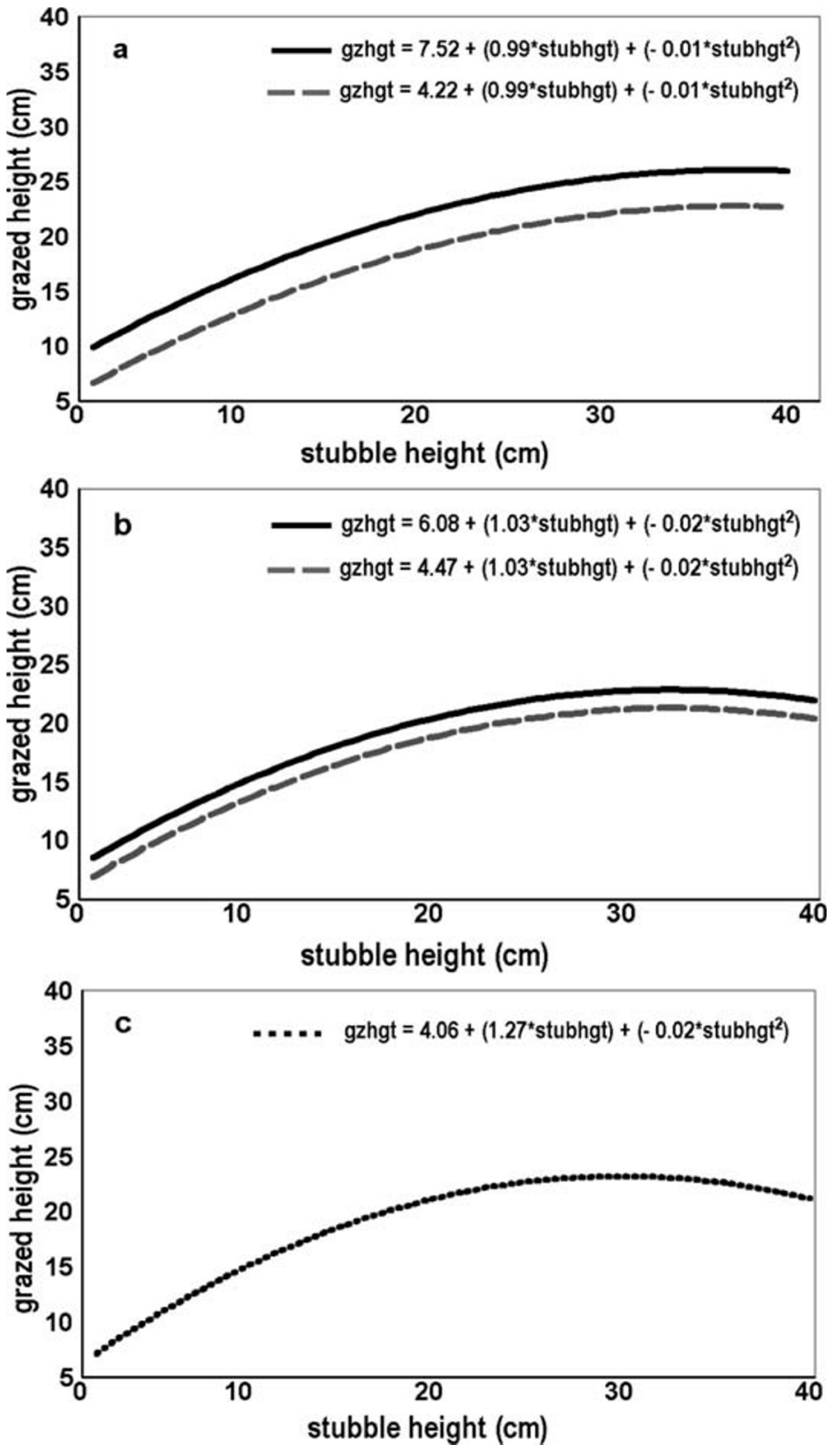

Figure 1. Grazing height of rough fescue herbage in spring in relation to the stubble height of standing litter at cumulative stocking rates $(\mathbf{a}, 0.48$ AUM • ha; b, 0.73 AUM • ha; and c, 1.46 AUM per ha) over a 6-d grazing trial conducted from 29 May to 4 June 2001, in 2 paddocks ( $\mathrm{A}[n=39]$ and $\mathrm{B}[n=40]$ or both paddocks $\mathrm{A}$ and $\mathrm{B} ; R^{2}=0.66,0.72$, and 0.78 for each set of equations, respectively). The equations were derived as the solutions for the covariates in the analysis of covariance within the framework of general linear models (Proc GLM; SAS 1999).

forage. The 3-day delay to achieve a similar response in Paddock A may have been the result of smaller plants, which may be less readily detected, or a greater availability of alternate preferred forages, which would reduce the attraction of the treated rough fescue plants.

\section{Forage Quality and Nutrient Distribution}

Steers derived progressively less nutritive benefit as grazing pressure increased because of increasing ADF and decreasing $\mathrm{CP}$ concentrations (\%) from the top to the bottom of the plant 
Table 4. Least-square means ( \pm 1 SEM) of Festuca campestris ADF and CP content in different height segments of ungrazed plants in relation to litter-removal treatments. Plants were harvested 6 June 2001, after the grazing trial.

\begin{tabular}{|c|c|c|c|c|c|c|c|}
\hline \multirow[b]{3}{*}{ Treatment: $^{1}$} & \multicolumn{5}{|c|}{ Acid detergent fiber } & \multicolumn{2}{|c|}{ Crude protein } \\
\hline & \multirow{2}{*}{$\begin{array}{c}\text { Litter } \\
\text { Control }\end{array}$} & \multicolumn{4}{|c|}{ Current growth } & \multirow{2}{*}{$\begin{array}{c}\text { Litter } \\
\text { Control }\end{array}$} & \multirow{2}{*}{$\frac{\text { Current growth }}{\text { Combined treatments }}$} \\
\hline & & Control & 14 & 7 & 2.5 & & \\
\hline $\mathrm{n}:$ & $10^{3}$ & 10 & 10 & 10 & 10 & $10^{3}$ & 40 \\
\hline \multicolumn{8}{|l|}{ Segment $^{2}$} \\
\hline 1 & $46 a^{4} \pm 0.4$ & $36.8 \mathrm{a} \pm 0.5$ & $37.9 a \pm 0.6$ & $36.6 a \pm 0.5$ & $36.4 a \pm 0.4$ & $5.8 \mathrm{a} \pm 0.4$ & $9.0 \mathrm{a} \pm 0.2$ \\
\hline 2 & $45.3 a \pm 0.3$ & $35.9 b \pm 0.7$ & $36.2 b \pm 0.8$ & $35.4 b \pm 0.5$ & $34.8 b \pm 0.5$ & $5.3 a \pm 0.3$ & $11.3 b \pm 0.2$ \\
\hline 3 & & $32.4 c \pm 0.8$ & $33.8 \mathrm{c} \pm 1.0$ & $31.6 c \pm 0.6$ & $31.9 \mathrm{c} \pm 0.5$ & & $13.3 c \pm 0.2$ \\
\hline$(3), 4,5$ & $44.6 \mathrm{a} \pm 0.7$ & $28.4 d \pm 0.7$ & $28.5 d \pm 0.7$ & $27.8 d \pm 0.9$ & $28.9 \mathrm{~d} \pm 0.5$ & $5.6 a \pm 0.4$ & $14.6 d \pm 0.3$ \\
\hline \multicolumn{8}{|l|}{ Source of variation } \\
\hline Treatment $(\mathrm{T})$ & $-^{5}$ & - & - & 2 - --------------. & 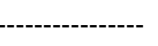 & - & 0.1 \\
\hline Segment (S) & 0.21 & -------------- & ------------ < & | ------------ & ---------------- & 0.31 & $<0.01$ \\
\hline $\mathrm{T} \times \mathrm{S}$ & - & ------------. & - & 3 -------------- & -------------- & - & 0.66 \\
\hline
\end{tabular}

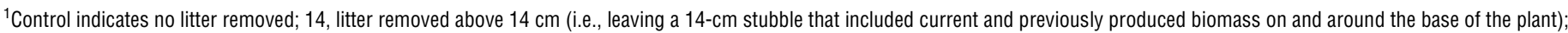
7, litter removed above $7 \mathrm{~cm}$; and 2.5, litter removed above $2.5 \mathrm{~cm}$.

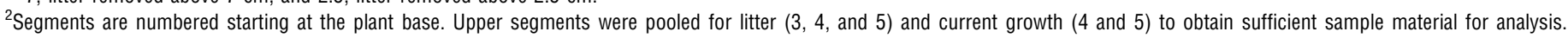
Each segment represents $20 \%$ of plant height and is not cumulative.

${ }^{3} n=9$ for the top sample, which is represented by the pooled segments 3 , 4, and 5

${ }^{4}$ Within a column, means followed by different letters differ significantly $(P<0.05)$.

${ }^{5}$ Not tested.

(Table 4). The marked decrease in CP toward the plant base is consistent with other species such as bluebunch wheatgrass (Agropyron spicatum [Pursh] Scribn. \& Smith; Willms et al. 1981). However, because litter produced the greatest impediment to grazing, it dictated the mass of nutrients harvested by the end of the grazing trial. Nevertheless, as grazing pressure increased, steers shifted their grazing to the undefoliated control plants (Fig. 1).

Steers derived most nutrients from treated plants. The total nutrients harvested in spring from the 2.5-, 7-, and $14-\mathrm{cm}$ stubble height treatments, averaged $10.8,6.5$, and 2.3 times that of the undefoliated control over the 6-day trial (data not shown). However, the proportion of nutrients consumed relative to that of the control also decreased during the trial from 13.9 to $9.2,8.2$ to 5.5 , and 2.7 to 2.0 for plants from the 2.5-, 7-, and 14-cm stubble height treatments, respectively. These relationships are obviously dependent on the availability of alternate forage plants in the paddock.

The low palatability of litter, which likely defines its protective effect to new growth in spring, is related to high ADF and low CP concentrations (Table 4). According to our study, the low quality of standing litter was similar $(P>0.05)$ along the entire length of the leaf, suggesting that its effectiveness as a deterrent would also be similar. However, the primary difference in the effectiveness of litter within the plant is likely an increase in density from top to bottom, which influences the ability of cattle to avoid litter.

\section{MANAGEMENT IMPLICATIONS}

Grazing management may be applied to utilize the effectiveness of litter in rough fescue plants as a grazing deterrent by carefully controlling grazing pressure in both fall and spring. Abundant litter not only provides stockpiled forage and reduces the cost of feeding preserved forage, but provides the rancher with a mechanism to limit the detrimental impact of grazing on rough fescue plants in spring. Nevertheless, the success of this practice would require close monitoring to ensure that both the timing and level of utilization remained appropriate to conserving rough fescue and range health in general.

The presence of standing litter serves as a deterrent to the utilization of current rough fescue growth in spring, but not necessarily the selection of fescue plants by cattle. Therefore, fall and winter grazing management coupled with spring grazing pressure, will impact the degree of defoliation on rough fescue in spring. This relationship must be recognized in a twoseason grazing scheme to predict the intensity of grazing on rough fescue and avoid the loss of condition and herbage yield in this species. Conversely, this information might also be used to facilitate safe spring grazing by protecting early growth, particularly at low grazing pressure. In any case, the effective use of litter as a protective barrier to grazing will require its integration with other management considerations such as the grazing period and grazing pressure, including stocking rates.

\section{ACKNOWLEDGMENTS}

The authors wish to thank Brian Laing, Barry Adams, Jennifer Carlson, and Richard Ehlert of the Public Lands and Forests Division, Alberta Sustainable Resources, and Toby Entz, Harriet Douwes, and Ryan Beck of Agriculture and Agri-Food Canada for their support and technical assistance. Additionally, we thank 2 anonymous reviewers for their helpful comments on improving the manuscript.

\section{LITERATURE CITED}

AOAC. 1995. Official methods of analysis. 16th ed. Washington, DC: Association of Official Analytical Chemists. Vol. 1.

BaKkeR, J. P., J. deLeeuw, and S. E. Van Wieren. 1984. Micro-patterns in grassland vegetation created and sustained by sheep grazing. Vegetation 53:153-161. 
Canada Soll Inventory. 1989. Soil landscapes of Canada-Alberta. Ottawa, ON: Research Branch, Agriculture Canada, Land Resource Research Centre. Publication 5237/B. 22 p.

Carr, D. E., and P. J. Lee. 2002. Post ANOVA comparison in SAS. Available at: http://toolkit.virginia.edu/cgi-local/tk/UVa_CLAS_2002_Spring_EVSC503-1/ displaymaterials:lab5handout.doc/lab5handout.doc. Accessed 2 May 2002.

DormaAR, J. F., AND W. D. WILlms. 1990. Sustainable production from the rough fescue prairie. Journal of Soil and Water Conservation 45:137-140.

Flores, E. R., E. A. Laca, T. C. Griggs, and M. W. Demment. 1993. Sward height and vertical morphological differentiation determine cattle bite dimensions. Agronomy Journal 85:527-532.

Ganskopp, D., R. AngeLL, AND J. Rose. 1992. Response of cattle to cured reproductive stems in caespitose grass. Journal of Range Management 45:401-404.

Johnston, A. 1961. Comparison of lightly grazed and ungrazed range in the fescue grassland of southwestern Alberta. Canadian Journal of Plant Science 41:615-622.

Laca, E. A., L. A. Shipley, and E. D. Reid. 2001. Structural anti-quality characteristics of range and pasture plants. Journal of Range Management 54:413-419.

McLean, A., AND S. WIKeEm. 1985. Rough fescue response to season and intensity of defoliation. Journal of Range Management 38:100-103.

Moss, E. H. 1944. The prairie and associated vegetation of southwestern Alberta. Canadian Journal of Research, Section C, Botany Science 22:218-229.

Moss, E. H., and J. A. Campbell. 1947. The fescue grasslands of Alberta. Canadian Journal of Research, Section C, Botany Science 25:209-227.

O'Reagain, P. J., and E. A. Grau. 1995. Sequence of species selection by cattle and sheep on South African sourveld. Journal of Range Management 48: 314-321.
Pfeiffer, K. E., and D. C. Hartnett. 1995. Bison selectivity and grazing response of little bluestem in tallgrass prairie. Journal of Range Management 48:26-31.

SAS InSTITUTE Inc. 1999. SAS/STAT users' guide. Version 8. Cary, NC: SAS Institute Inc. 2552 pp.

Steel, R. G. D., J. H. TorRie, And D. A. Dickey. 1997. Principles and procedures of statistics: A biometrical approach. 3rd ed. New York: McGraw-Hill. 256 p.

Strong, W. L., and K. R. LegGat. 1992. Ecoregions of Alberta: Volume 1. Edmonton, AB, Canada: Alberta Forestry, Lands, and Wildlife, Land Information Services. Publication No. T/245. $59 \mathrm{p}$.

WiLLMS, W. D. 1991. Cutting frequency and cutting height effects on rough fescue and Parry oat grass yields. Journal of Range Management 44:82-86.

Willms, W. D., A. W. Bailey, and A. McLean. 1980. Effect of clipping or burning on some morphological characteristics of Agropyron spicatum. Canadian Journal of Botany 58:2309-2312.

Willms, W. D., A. W. Bailey, A. Mclean, and C. Kalnin. 1981. Effects of fall clipping or burning on the distribution of chemical constituents in bluebunch wheatgrass in spring. Journal of Range Management 34:267-269.

WilLms, W. D., AND L. M. RoDE. 1998. Forage selection by cattle on fescue prairie in summer or winter. Journal of Range Management 51:496-500.

Willms, W. D., S. Smoliak, and J. F. Dormaar. 1985. Effects of stocking rate on rough fescue grassland vegetation. Journal of Range Management 38: 220-225.

Wroe, R. A., S. Smoliak, B. W. Adams, W. D. Willms, and M. L. Anderson. 1988. Guide to range condition and stocking rates for Alberta grasslands. Edmonton, Canada: Alberta Forestry, Lands, and Wildlife. 33 p.

ZAR, J. H. 1999. Biostatistical analysis. 4th ed. Upper Saddle River, NJ: PrenticeHall. $663 \mathrm{p}$. 